\title{
Aprendendo a investigar através de uma atividade investigativa sobre Ciência Forense e Investigação Criminal
}

Ana Paula Sebastiany

Michelle Camara Pizzato

Tania Denise Miskinis Salgado

\section{Resumo}

O presente trabalho tem por objetivo avaliar uma proposta didática sobre a temática da Ciência Forense e a Investigação Criminal, e identificar as curiosidades e interesses do público participante. Nesse sentido, as atividades foram organizadas sob a forma de um Ambiente Interativo de Aprendizagem (AIA), de âmbito informal e presencial ligado ao Ensino de Ciências, como estratégia para a aprendizagem de atitudes investigativas e a divulgação da Ciência e da Tecnologia. O AIA proposto está orientado para abordar as ciências pela aproximação destas com o cotidiano utilizando metodologias investigativas. Esta orientação se baseia no Modelo Didático Investigativo (Porlán, 1993), o qual propõe a investigação como metodologia didática em alternativa aos métodos passivos de ensino. Além disso, para que esse ambiente tivesse caráter lúdico buscou-se inspiração nos jogos de RPG - Roleplaying Game. E escolhemos como eixos temáticos a Ciência Forense e a Investigação Criminal, considerando que o AIA só seria significativo para o estudante se estivesse ligado a seus interesses, curiosidades, necessidades e objetivos pessoais. Afinal, as pessoas aprendem melhor em um contexto realista, usando o que já sabem e desenvolvendo habilidades a partir disso. E, por serem temas de rara abordagem no ensino formal e informal, mas de grande interesse pelo público em geral.

Palavras-chave: ciência forense, contexto informal, educação em ciências.

\section{Abstract}

Learning to research by a investigative activity on forensic science and criminal investigation: a preliminary analysis

The present study aims to evaluate didactic proposal on the issue of Forensic Science and Criminal Investigation, and identify the curiosities and interests of the participating public. In this sense, the activities were organized in the form of an Interactive Learning Environment(AIA), at the informal and face on the Teaching of Science as a strategy for learning and dissemination of investigative attitudes Science and Technology. The AIA is proposed to address science-oriented approach by using these with the daily investigative methodologies. This guidance is based on Model Guided Investigative (Porlán, 1993), which proposes the investigation as an alternative teaching methods to passive methods of teaching. Furthermore, that this environment had sought to playful inspiration in games RPG - Roleplaying Game. And we chose themes as the 
Forensic Science and Criminal Investigation, considering that the AIA would only be meaningful to the student if connected to their interests, curiosities, needs and personal goals. After all, people learn best in a realistic context, using what they already know and develop skills from that. And because they are rare approach issues informal and informal education, but of great interest to the general public.

Keywords: forensic science, context informal, science education.

\section{Introdução a problemática}

Ensinar e formar crianças, adolescentes e jovens parece, hoje, ser um dos maiores desafios de toda a ação humana, pois a escola tem sido considerada, muitas vezes, apenas um local de preparação na qual as alegrias e as curiosidades do presente não são consideradas. Sendo assim, as aprendizagens que são estimuladas fora das instituições formais estão se tornando cada vez mais amplas, atrativas e instigantes se comparadas a teorias e fórmulas ensinadas nas instituições escolares.

De maneira geral, a realidade do sistema educacional remete reflexão sobre o verdadeiro papel não só das instituições de ensino e dos professores, mas também daqueles que são o principal quando se fala em educação: os alunos. "O que pensam?" " O que anseiam?" "O que desejam?". Sendo assim, a escola não só deveria contribuir ao conhecimento, deveria também preocupar-se em oferecer aos alunos uma formação integral que permita uma formação para tomada de decisões e ao desenvolvimento da capacidade crítica na busca de soluções aos problemas que vêm sendo propostos pela humanidade (Martíns, 2002).

Deste modo, observa-se que o ensino predominante nas salas de aula não gera expectativas por parte dos alunos para a aprendizagem das ciências e isto se reflete em suas atitudes e pelo desinteresse pelo que aprendem. Isso é reconhecido por pesquisadores da área de ensino e tem sido associado à falta de conexão entre o que se ensina na escola e a vivência dos alunos fora dela (Gil, Carrascosa e Martínez, 1991; Bello, 2000; Pozo e Crespo, 2000; Sobes e Vilches, 2000; Acevedo, 2004), dificultando que o aluno perceba uma interconexão entre o conhecimento e sua realidade e que veja a ciência como algo pouco prático e sem relação com ele e com seu meio. Além disso, apesar de reconhecerem a importância e a atualidade da ciência em virtude de sua presença em todos os ambientes e materiais que os cerca, os alunos não são capazes de usar a ciência que eles aprenderam na escola para solucionar problemas do chamado "mundo real" (Peña, 2001; Hoerninge Pereira, 2004).

Considera-se que essa problemática possa ser reflexo da forma tradicional de ensino na escola, onde a memorização é constantemente exigida e há reprodução de conceitos em detrimento da construção coletiva ou individualizada destes, acabando por desestimular os alunos (Calazans, 1996; Delicio, Gandini e Nunes, 2007). Dessa forma, torna-se impossível aos 
alunos sozinhos, submetidos a esse modelo de ensino, conseguir articular o conhecimento aprendido em aula com as diversas situações complexas com que eles vierem a se deparar (Bastos, et al, 2003).

Outro aspecto que pode estar relacionado a esta problemática diz respeito à disciplinarização excessiva do conhecimento no ensino formal. Neste sentido, a separação do conhecimento em disciplinas (Química, Física, Biologia e Matemática, entre outras) pode implicar em ficarmos isolados, fechados nas nossas ideias e na nossa sala de aula e não olharmos para o que se passa à volta. Essa fragmentação vai contra o modo como cada um de nós aprende e conhece o mundo. Afinal, não é assim que nós explicamos a realidade que nos envolve e também não é assim que as crianças e os jovens a querem aprender (Galvão, 2003).

Sabemos que a criança e o ser humano em geral são naturalmente curiosos, investigativos e observadores. Na infância, estas características podem ser distinguidas pelas atitudes das crianças em relação a tudo que vivem, tanto que a maioria se diverte e gosta da escola e do que aprende nela, pois é a presença dessas características que as estimula a aprender, a entender, a descobrir e a inventar. Mas, à medida que os estudos escolares vão avançando, tais características humanas naturais vão perdendo espaço. Essa situação pode estar relacionada com o fato de que muitos alunos não entendem o que se tenta ensinar; outros, ainda, se aborrecem profundamente nas aulas ao se darem conta de que o que lhes é ensinado não responde a seus interesses (Delval, 2001). Tal situação vem se perpetuando ao longo dos anos e tem sido também apontada como um dos fatores que tem contribuído para afastar os estudantes do ensino de ciências (Rosa, Heineck e Rosa, 2004).

Porém, o fato do ensino de ciências não desenvolver e/ou não considerar a atitude investigativa dos alunos, implica que este não está capacitando os alunos a pensar, a falar, a sentir e a atuar frente ao mundo que nos cerca. Nesta perspectiva, fazer ciência na escola deveria se constituir como uma atividade no marco de um sistema social complexo cuja finalidade consistiria na construção significativa de novas maneiras de pensar, falar, sentir e atuar que permitissem explicar e transformar o mundo que nos rodeia. Ou seja, a prática educativa deveria objetivar um novo tipo de pessoa, com personalidade inquisitiva, flexível, criativa, inovadora, tolerante e liberal que pudesse enfrentar a incerteza e a ambiguidade, através de um processo de busca, questionamento e construção de significados que poderia ser chamado de "aprender a aprender" (Moreira, 2005).

Entende-se que "conhecer" não é o ato através do qual um sujeito é transformado em objeto e recebe passivamente os conteúdos que outro lhe dá ou lhe impõe. O conhecimento, pelo contrário, exige uma presença curiosa do sujeito em face do mundo (Freire, 1983). Por sua vez, um ensino estimulante é aquele que ajuda as crianças e os jovens a não ter medo, a fazer perguntas, a olhar para o mundo e a procurar respostas. Em outras palavras, é preciso que os alunos vivam situações de aprendizagem que os estimulem a querer aprender, a criar uma relação 
prazerosa com o aprender. Sendo assim, ao invés de perguntar o que é que os alunos devem aprender sobre ciência?, deveria-se perguntar o que fará os jovens quererem aprender ciência?

Nesse sentido, pensamos que um dos caminhos para se alcançar respostas a esta questão poderia se dar através do ensino informal (Asensio, 2001) pois a educação, para existir, não se vincula unicamente à estrutura escolar. São diversos os estudos, nacionais e internacionais, que permitem afirmar que aprender ciências é um longo e complexo processo que não se encerra no tempo da escolarização ou entre os muros da escola (Gaspar, 1992; Rodrigues e Martins, 2005 e Rosenfeld, 2005). Apesar de passar despercebida na maioria das vezes, a ciência está em praticamente tudo que faz parte da vida. Cinema, TV, veículos automotivos, vacinas e eletrodomésticos são apenas alguns exemplos de como a ciência está mais próxima das pessoas do que se pode imaginar.

Hoje, mais do que nunca, é necessário que todo o indivíduo esteja munido de habilidades, como ser capaz de argumentar, de decidir, de emitir opiniões, de propor soluções, de pensar criticamente entre outros. Por isso, há que se transpor os muros da escola - local privilegiado, formal de educação - e as paredes das salas de aula - muitas vezes limitativas e redutoras - e estender-se a outros espaços (Freitas e Martins, 2005). De maneira informal aprende-se muitas coisas e, por isso, precisa-se estimular esse tipo de ensino (Rosenfeld, 2005). No entanto, as atividades desenvolvidas e os ambientes de aprendizagem normalmente utilizados no ensino informal estão estruturados, geralmente, sob uma perspectiva expositiva. Por isso, os alunos se sentem pouco atraídos para essas atividades e ambientes, uma vez que há pouco estímulo à curiosidade e à atitude investigativa ${ }^{1}$.

Sendo assim, a proposta deste trabalho² é a de apresentar as atividades desenvolvidas em um curso de caráter informal (Sebastiany, et al 2012), orientadas para o desenvolvimento de atitudes investigativas nos sujeitos envolvidos, identificando as curiosidades e interesses desses e realizando uma avaliação da proposta. Nesse sentido, pretende-se organizar as atividades sob a forma de um Ambiente Interativo de Aprendizagem $\left(\mathrm{Al}^{3}\right)^{3}$ orientado pelo Modelo Didático

\footnotetext{
${ }^{1}$ Estamos tratando como atitude investigativa, como aquelas associadas a curiosidade. Estamos entendendo a curiosidade como uma conduta relacional (Maturana, 2002), que pode ser identificada através de algumas ações tais como, formulação de perguntas, formulações de hipóteses, coleta de dados, proposição de procedimentos ou de estratégias para resolução do problema, identificação do problema, e outras (Brasil, 1998).

${ }^{2}$ Esse trabalho trata de uma proposta vinculada a uma pesquisa de mestrado.

${ }^{3} \mathrm{AIA}$ é um ambiente caracterizado pela interação entre os sujeitos e materiais que o constituem, e esse proporciona um trabalho de caráter colaborativo, interativo e investigativo. Os AIA são ambientes de aprendizagem planejados para oferecer situações-problema e recursos
} 
Investigativo (Porlán, 1993), o qual propõe a investigação como metodologia didática e como alternativa aos métodos passivos de ensino. Este modelo foi escolhido por possibilitar o desenvolvimento de uma perspectiva sistêmica e complexa sobre a ciência e o mundo que nos cerca.

O modelo didático investigativo adota uma perspectiva construtivista, tanto no plano individual como social. Tal modelo consiste no tratamento de situações sob forma de problemas abertos, através das quais os alunos podem participar na construção dos conhecimentos, ou seja, que os alunos elaborem modelos complexos para entender e atuar sobre o mundo e, desta forma, a tendência à passividade tende a ser superada. Este modelo parte do reconhecimento e da consideração dos interesses e das ideias dos alunos. O professor, dentro desta perspectiva, deve trabalhar com a problemática social-ambiental e cultural, integrando o conhecimento disciplinar, o conhecimento cotidiano, promovendo a construção livre e significativa de conceitos, procedimentos, atitudes e valores, tendo papel ativo como coordenador e orientador do processo de investigação desenvolvido nas aulas (García Pérez e Porlán, 2000; García Pérez, 2000; Harreset al., 2005; Novais et al, 2008; Predebon, 2009). Além disso, o estímulo ao uso de habilidades investigativas para a resolução de problemas, como proposto por este modelo, também pode influenciar na aprendizagem dos alunos no ensino formal.

Outro aspecto que acreditamos estimular o interesse pelas ciências é o caráter lúdico dos AIA. Para isso, busca-se inspiração nos jogos de RPG. Roleplaying Game (RPG) significa"Jogo de Representação de Papéis", no qual os jogadores assumem uma identidade dentro de uma trama e de um cenário, definidos pelo jogo, para completarem uma busca ou aventura. Diversos trabalhos têm sido realizados, em diferentes componentes curriculares e temas transversais, relacionando os jogos com o desenvolvimento de conceitos e de atitudes. O RPG Pedagógico incentiva a criatividade, a participação, a leitura e a pesquisa, além de ser de fácil aplicação a quaisquer matérias e conteúdos didáticos, para crianças, adolescentes e adultos (Riyis, 2003). A atividade lúdica, sob esse olhar, se coloca como uma vivência do momento de uma forma integradora e prazerosa. As atividades lúdicas são uma necessidade do ser humano, independente de sua faixa etária, e através delas, é possível ter contato mais profundo consigo e com o outro. Tais atividades se caracterizam como atividades não impostas e sim compartilhadas, propiciando que seus participantes se "entreguem", integrando a ação, o pensamento e a emoção.

(bibliográficos, experimentais, tecnológicos) aos participantes, de modo que eles possam, ao interagir com tais recursos, expressar suas ideias, resoluções, dificuldades e perguntas, a fim de resolver o problema proposto. Os AIA favorecem uma atitude exploratória, cooperativa e autônoma, buscando contribuir para o desenvolvimento de um espírito de abordagem de problemas desafiadores e tomada de decisões sobre estes.

256 DOI: Em andamento.

R. Bras. de Ensino de C\&T 
Considerando que o AIA só terá significado para o aluno se estiver ligado a seus interesses, curiosidades, necessidades e objetivos pessoais, escolhemos como temática a "Ciência Forense e a Investigação Criminal". A Ciência Forense é uma área interdisciplinar que envolve física, biologia, química, matemática e várias outras ciências de fronteira. Seu objetivo é dar suporte às investigações relativas à justiça civil e criminal. Em investigações de crimes, o foco principal do profissional forense é confirmar a autoria ou descartar o envolvimento do(s) suspeito(s). As técnicas empregadas permitem que seja possível identificar, com relativa precisão, se uma pessoa, por exemplo, esteve ou não na cena do crime a partir de uma simples impressão digital, ou então um fio de cabelo encontrado no local do crime. Em algumas situações, os especialistas forenses utilizam a tecnologia dos testes de DNA, as análises da autenticidade de obras de arte e de documentos ou, ainda, o exame de combustíveis adulterados (Chemello, 2006).

O desenvolvimento de temas transversais, como o exposto, surge como uma proposta para auxiliar na construção de um saber mais sistêmico e contextualizado. Em especial, acredita-se que o envolvimento da Ciência Forense, de rara abordagem no contexto escolar, pode vir a ampliar a diversidade de atividades oferecidas no ensino formal. Finalmente, esse tema pode proporcionar o estímulo à curiosidade, à pesquisa, à troca de informações, à criatividade e à busca por carreiras científicas e tecnológicas, promovendo uma aprendizagem que extrapola as barreiras físicas das escolas. Nesse contexto, o AIA estimula uma variedade de atitudes, desde a observação, a manipulação, a curiosidade, a interrogação, o raciocínio, a experimentação, o direito à tentativa e ao erro, o trabalho de análise, de síntese e da criatividade, em cuja conjugação se encontra um marco essencial para o desenvolvimento do indivíduo.

Portanto, consideramos que o AIA estruturado sob forma de jogos de RPG, orientado pelo Modelo Didático Investigativo, tendo como tema a "Ciência Forense e a Investigação Criminal" pode favorecer de forma significativa o desenvolvimento de atitudes investigativas Nesse sentido, este trabalho apresenta uma proposta alternativa à abordagem do processo educacional por meio de espaços de formação e de investigação, objetivando contribuir para as discussões sobre a utilização de ambientes interativos de aprendizagem de âmbito informal.

\section{Contexto da Pesquisa}

O contexto da pesquisa constitui-se da implementação de uma proposta didática, sob forma de um curso de extensão, intitulada "Detetive por um dia - aprendendo a investigar por meio da Ciência Forense" promovida pelo Centro Universitário UNIVATES ${ }^{1}$ (Lajeado/RS), durante o

\footnotetext{
${ }^{1} \mathrm{~A}$ Univates é uma instituição comunitária, sem fins lucrativos e com gestão democrática e participativa.
}

R. B. E. C. T., vol 8, núm. 4, set-dez.2015 ISSN - 1982-873X

DOI: Em andamento. 
segundo semestre de 2011.Para tanto, foi produzido um Ambiente Interativo de Aprendizagem (AIA) sob forma de uma cena de crime, composta por um cenário (simulação de um crime fictício), personagens (sujeitos) e a problemática (Ciência Forense e Investigação Criminal).

O AIA foi constituído por dois cenários físicos: a "cena do crime" - contendo pistas para a resolução do mistério - e o "laboratório de análises forenses" - no qual os participantes pudessem realizar experimentos e pesquisar dados relacionados à trama. A esses cenários, foram agregados diferentes materiais, tais como lupas, luvas, microscópios, pinças, bicos de Bunsen, vidrarias, sacos plásticos para coleta das amostras, kits de reagentes para as análises químicas, computador contendo banco de dados e entrevistas a suspeitos e testemunhas, bibliografia para pesquisa e entre outros equipamentos necessários para a resolução do caso.

As atividades que compõem aproposta didática foram estruturadas em cinco momentos, conforme será descrito abaixo, as quais foram aplicadas em dois encontros, totalizando 10 horas. Cabe destacar que as etapas mencionadas foram realizadas com doze alunos de Ensino Médio, organizados em grupos de quatro integrantes separados uns dos outros, uma vez que a interação entre eles poderia interferir, em alguma medida, na explicitação, na identificação, no desenvolvimento e na resolução da situação proposta.

\section{Momento 1:Apresentando a proposta didática}

Nessa primeira etapa da proposta didática, os pesquisadores ${ }^{1}$ recepcionaram os alunos e fizeram suas apresentações, assim também como a apresentação da proposta sobre a temática da "Ciência Forense e da Investigação Criminal". Além disso, foi aplicado um questionário respondido individualmente por cada aluno -, a fim de identificar as suas curiosidades e

Pertencendo à comunidade na qual está inserida, a Univates reverte todos os seus resultados em investimentos na própria instituição ou na comunidade.Com sede em Lajeado, a UNIVATES tem uma trajetória que se confunde com a história recente do Vale do Taquari. Em 17 de janeiro de 1969, surgiram em Lajeado os primeiros cursos superiores, como extensão da Universidade de Caxias do Sul, passando para uma fundação local em 1972. Em 1997, surge a UNIVATES, com a fusão das duas faculdades então existentes. Em 1999, a UNIVATES - mantida pela Fundação Vale do Taquari de Educação e Desenvolvimento Social (FUVATES) - foi credenciada como Centro Universitário. A autonomia universitária possibilita-lhe traçar suas metas e elaborar as estratégias para, em consonância com as necessidades locais e tendências mundiais, alcançar seu objetivo de geradora e difusora do conhecimento.

${ }^{1}$ Os pesquisadores são osautores 1 e 2 desse trabalho, que desenvolveram a proposta didática em conjunto com os alunos. 
interesses no curso. Em seguida, foi explicado de forma mais específica aos alunos como a proposta de trabalho seria desenvolvida e o que fariam durante os encontros - sendo convidados a desvendar um crime fictício, o qual foi elaborado especialmente para essa atividade, assumindo o papel de peritos forenses, cujo objetivo era a procura de provas na tentativa de solucionar um crime. Os pesquisadores relataram, ainda, que essa atividade seria realizada sempre em grupos assim como apresentadas pelas séries televisivas, por exemplo, CSI (sigla referente a Crime Scenelnvestigation) -, ou seja, uma equipe, que vai desenvolver um trabalho em conjunto de forma cooperativa e integrativa . Cabe destacar que os alunos não tiveram acesso à história do crime, ele serviu apenas para os pesquisadores desenvolverem a proposta didática.

Momento 2: Identificando as hipóteses dos alunos versus primeiras ideias sobre o crime

Nesse momento, os alunos foram convidados a ouvir o relato do oficial de justiça(Anexo 1) que apresenta sucintamente o caso da história fictícia. Depois, foi solicitado que os alunos elaborassem perguntas nos seus respectivos grupos (questionamentos iniciais) e as registrassem em uma folha, caso fosse possível interrogar o oficial a respeito do que encontrou na cena do crime. Em seguida, realizou-se uma conversa, com cada pequeno grupo. Esta conversa tinha como objetivo identificar as possíveis hipóteses (o que pensam) e procedimentos (como pensam em fazer), a fim de solucionar o crime em questão e de identificar a percepção dos alunos sobre a função de um perito forense. Para finalizar, os alunos receberam alguns materiais como, luvas, propés e toucas.

\section{Momento 3: Conhecendo a cena}

Os alunos foram conhecer a cena do crime. Primeiramente, foi solicitado que apenas observassem (não tocassem em nada) olhando-a na parte externa, que estava isolada. Distante da cena do crime, os grupos se reuniram para fazer suas primeiras anotações, observações, e planejarem o próximo passo a ser seguido para desvendar o crime. Em seguida, os alunos entraram na cena do crime e começaram a procurar e identificar as possíveis evidências, as quais foram orientadas pelas suas hipóteses. Quando essa etapa foi concluída, os alunos regressaram a sala de origem e elaboraram uma síntese das suas primeiras ideias a respeito do crime.

\section{Momento 4: Analisando a cena}

A partir do conhecimento da cena, os alunos se tornaram os detetives e começaram a procurar evidências na cena do crime, seguida da análise das mesmas, a fim de solucionar o problema. Os pesquisadores ficaram responsáveis por orientar e fazer com que os alunos se tornassem cientes dos materiais que estavam disponíveis de serem solicitados. Além da cena do crime, os alunos puderam fazer consultas em material bibliográfico(banco de dados no computador), o qual continha textos explicativos e roteiros para práticas, referente às evidências de sangue, impressão digital, pegadas, balística, entorpecentes e etanol, além de análises que achassem necessárias no laboratório forense. Por exemplo, no material das impressões digitais, 
aparecia uma descrição do que vem a ser uma impressão digital, as diferenças entre elas, onde elas podem ser encontradas, o porquê e como são formadas. Também, uma descrição dos métodos que podiam ser usados para coletá-las, assim como podem ser analisadas. Para que fosse possível aos alunos identificar a quem pertence cada uma das impressões digitais recolhidas, foi necessário compará-las com as digitais de uma base de dados, tentando encontrar os traços característicos de cada uma para chegar ao possível suspeito. Para isso criou-se um banco de dados, recolhendo impressões digitais de diversas pessoas e as mesmas foram organizadas em fichas que continham algumas informações, como se fosse uma ficha cadastral (um exemplo disso é mostrado no Anexo 2).

Para uso dos peritos forenses, os grupos de estudantes, criou-se blocos de detetive (Anexo 3), pirâmides que sinalizam cada um dos tipos de evidências que podem ser identificadas (Anexo 4), fichas para a anotação de cada uma dessas evidências (Anexo 5) e uma ficha cadastral (Anexo 6) para que os participantes possam registrar as informações necessárias quanto as pessoas envolvidas na trama, a fim de auxiliá-los na análise e conclusões. Concretamente, os pesquisadores procuraram orientar o "olhar" dos alunos frente aos registros que os mesmos poderiam fazer referente à coleta de dados e análises realizadas. Cabe destacar que os pesquisadores se fizeram presentes enquanto da realização das atividades pelos grupos, principalmente, na coleta das evidências e na análise das provas. Dessa forma, foi possível instigálos a discussão e a reflexão sobre o que pensavam fazer e o que estavam fazendo.

\section{Momento 5: Desvendando o caso}

Com o intuito de finalizar a proposta didática, foi proposto que o grupo de trabalho elaborasse um laudo - contendo as evidências coletadas, as análises que realizaram e como fizeram para avaliar as provas -, relatando as suas conclusões e apresentando quais foram os procedimentos que utilizaram para desvendar o caso. Por fim, os alunos responderam individualmente a um questionário, para que pudessem fazer uma avaliação do curso e da proposta desenvolvida.

\section{Metodologia da Investigação}

Esta pesquisa se inscreve na perspectiva de caráter qualitativo de estudo de caso (Yin, 2005), tomando como sujeitos de investigação doze alunos do Ensino Médio de uma escola da Rede Estadual do Rio Grande do Sul, situada na cidade de Estrela, participantes do estudo para a implementação do AIA.Os sujeitos participantes desse estudo foram escolhidos intencionalmente, de acordo com sua representatividade como casos prototípicos e pela disponibilidade de participarem da pesquisa. Além disso, para a escolha dos estudantes foi observado seu interesse pela temática, e sua postura, ou seja, alunos que em contexto formal de ensino normalmente envolvem-se e realizam as atividades propostas, demonstrando, em graus distintos, seu 
comprometimento. A intenção desse estudo de caso era de trabalhar com estudantes que tivessem comportamentos bastante diferentes, como aqueles que em sala de aula aparentam ser curiosos por natureza e, em contraposição, alunos que não tenham essa postura evidenciada nas suas práticas escolares. Cabe destacar que essa escolha só foi possível devido à imersão da pesquisadora - professora dos alunos nessa escola - no convívio escolar com os sujeitos da pesquisa.

Os dados coletados correspondem aos materiais produzidos pelos sujeitos durante a participação no AIA, especificamente às respostas ao dois questionários (inicial e final). Utiliza-se a 'análise de conteúdo' (Moraes e Galliazzi, 2007) como estratégia de análise qualitativa de dados. Esse trabalho tem como objetivo identificar as curiosidades e interesses do público participante no curso, percebendo o que os levaram a fazer parte do mesmo, o porquê se inscreverem e o que esperavam aprender. Além disso, busca-se realizar uma avaliação da proposta didática planejada e desenvolvida.

\section{Análise dos dados}

\section{Questionário Inicial}

Quando os alunos foram questionados sobre a sua intenção por participar dessa atividade explicitaram como principais motivos o interesse e a curiosidade pela temática abordada e/ou sobre os procedimentos de uma investigação criminal, assim como a função dos peritos e detetives:

"curiosidade e interesse sobre essa área de investigação, criminalística e assuntos diversos que abordam esses temas.";

"algo interessante, algo diferente, e ao mesmo tempo me motivou a querer saber mais sobre o trabalho, sobre o que iria acontecer."

"o interesse sobre investigações, o trabalho dos detetives e sobre crimes."

Além disso, pode-se perceber, nas falas dos alunos, que esses motivos estão associados por algum tipo de prazer e/ou emoção:

"o que me levou a participar foi por eu gostar disso e ter curiosidade sobre esses assuntos."

"eu sempre gostei de seriados criminais, como 'Dexter' e 'CSI'. Sempre quis participar de uma investigação."

"o assunto, que é um assunto muito interessante, pois, afinal, crime, desvendar mistério, não existe nada mais legal que isso, e poder participar e saber como é, é muito bom!".

DOI: Em andamento. 
Outra ideia que aparece, é quanto à oportunidade de aprender:

"uma chance para ter mais conhecimento nesta área"

"a curiosidade e a vontade de aprender coisas novas.".

Quanto ao que esperavam aprender, os alunos mencionaram, coisas novas e interessantes, oportunidade de desenvolverem determinadas habilidades, como raciocínio lógico e o trabalho em equipe de forma cooperativa, associado à solução de crimes:

"muita coisa nova e interessante";

"muitas coisas novas, muitos truques, espero ficar mais atenta aos detalhes, como desvendar crimes, por mais impossíveis que sejam";

"como prestar mais atenção a detalhes e como agir em momentos como esse abordado pelo trabalho";

"certamente, além de qualquer conhecimento, acho que o trabalho em equipe, algo que as vezes é difícil para mim, tenho dificuldade em aceitar opiniões, $e$ atividades como esta me fazem ter que aprender. Isso, sem contar o ensino sobre Ciência Forense".

Cabe destacar a ênfase dada pelos alunos em aprender a desenvolver algumas atitudes que são essenciais para a nossa aprendizagem, como por exemplo, a observação, a análise e postura critica frente a uma situação problema:

"espero aprender a observar melhor certos acontecimentos e ter mais censo critico"

"aprender a pensar de forma lógica para solucionar um caso criminal"

"espero aprender a analisar todos os fatos ao meu redor, aguçando minha atenção"

"espero aprender a "avaliar" e a 'julgar', se for preciso"

Tais considerações permitem entender que os alunos procuram nesse espaço de aprendizagem desenvolver conhecimentos (conceituais, procedimentais e atitudinais) que são pouco explorados no ensino formal - a escola. Destaca-se também a possibilidade de o aluno fazer parte do processo de aprendizagem, atuando como protagonista e não como um mero expectador:

"acho que não é um assunto muito interessante, estudar corpos e afinal ser um detetive" 
"eu espero aprender sobre os assuntos e saber como posso investigar um crime mesmo se for apenas para entender melhor alguns filmes"

"espero aprender algo sobre o trabalho dos detetives e policiais, agindo em busca de solucionar crimes com algumas pistas, tentando sempre fazer justiça"

Quando questionados sobre o que fariam durante os encontros, aparecem ideias já mencionadas anteriormente, como aprender coisas novas e interessantes, desenvolver algumas atitudes e procedimentos diante da proposta didática - pensar, observar, analisar e avaliar:

"coisas interessantes que tragam muito aprendizado"

"acho que farei coisas diferentes, teorias, pensar, raciocinar bastante"

"acho que vou ter que pensar muito, avaliar vários detalhes e assim tentar chegar em algumas conclusões"

"analisar cenas, fatos e situações diversas, detectando detalhes importantes para o projeto"

"investigar um crime, analisando as evidências e o fatos"

De forma mais especifica, os sujeitos pensaram inicialmente que a atividade seria a simulação ou apresentação de informações sobre um crime, e que nesse, iriam poder manusear e analisar corpos humanos e DNA.

"Suponho que vai ser simulado um crime, e vamos ser detetives, achar suspeitos e criminosos. Ah, mexer em corpos, ser uma coisa bem real mesmo"

"Abrir corpos, olhar DNA em microscópio"

"Acho que vou conhecer algum caso de morte, crime, e tentar solucionar ele, achando o culpado"

Cabe destacar a postura ativa assumida pelos sujeitos na atividade, ou seja, a incorporação de uma identidade dentro da trama - detetives ou investigadores - na tentativa de desvendar um suposto crime e conseguirem prever como, o que e porque ele aconteceu.

"descobrir como ocorreu o crime."

"ser uma investigadora e solucionar um crime, descobrindo exatamente o que aconteceu"

"acho que vou analisar uma cena criminal, saber como aconteceu o crime, o que aconteceu no crime e porque o crime aconteceu. Como se eu fosse uma detetive"

"tentar desvendar um mistério ou um caso criminal"

DOI: Em andamento. 


\section{Questionário final}

A primeira pergunta do questionário aplicado ao final da proposta solicitava que os alunos mencionassem o que mais tinham gostado e que explicassem a sua resposta. Nesse sentido, eles explicitaram os materiais utilizados na análise das evidências, os procedimentos necessários que devem ser adotados antes de entrar na cena do crime, assim como a coleta das evidências, e o primeiro contato com o espaço físico da cena:

"o que eu mais gostei foi dos materiais usados para descobrir as coisas, o pó de alumínio, as reações, tirar as amostras, os cuidados que se deve ter etc."

"foi a nossa primeira ida ao local do crime, estávamos com muita expectativa, tivemos que usar luvas e propés como se fosse algo verdadeiro. Também gostei de termos que analisar as evidências, digital, o liquido do copo, as pessoas e etc"

As respostas que apresentaram mais representatividade foram as que mencionaram que gostaram de estar em uma situação real - local do crime - procurando, coletando e analisando as evidências a fim de encontrar os possíveis suspeitos:

"gostei de procurar as pistas e analisar a cena do crime."

"eu gostei mais da parte de coletar as provas que estavam na cena do crime, também gostei de analisar estas provas para determinar a que suspeito chegaríamos."

"gostei de tudo em geral, mas objetivamente achei muito interessante a parte da criminalística de fato. Encontrar e remover balas e vestígios da mesma, coletar impressões digitais, DNA's e fios de cabelo, muito chamativo mesmo."

Nesse sentido, outra ideia que apareceu, foi de tentar relacionar as evidências coletadas, as análises realizadas e os depoimentos das pessoas envolvidas para descobrir o que de fato aconteceu e quem poderia ser o assassino:

"o que eu mais gostei foi de tentar descobrir como a vítima tinha morrido, pois me deixava bastante confuso e eu tinha muitas ideias e possibilidades"

"todas as atividades foram muito boas. Mas a que eu mais gostei, foi a de procurar e identificar quem realmente era o suspeito. Todos os depoimentos, testes de impressão, etc.... foram pistas muito importantes para que nós pudéssemos encontrar quem era o assassino"

Podem-se citar as ideias que mencionam a proposta didática desenvolvida, ou seja, a temática abordada, as atividades desenvolvidas e a orientação metodológica de caráter investigativo e construtivista que proporcionaram que a simulação do crime fictício tenha sido 
concebida como "quase real". Os sujeitos consideraram como uma oportunidade única, na qual, poderiam utilizar seus conhecimentos em ciências:

"gostei do trabalho como um todo, do modo como isso pareceu real, com tantos detalhes a observar. Foi uma simulação quase perfeita de um crime!" "gostei do trabalho em geral, do local do crime, do modo como pudemos desvendar o caso, dando uma de "detetive", questionando e descobrindo lou não descobrindo) as coisas."

"gostei do assunto, da criatividade do tema e da dinâmica que proporcionou. Foi algo único que provavelmente não teríamos outras chances de realizar. Enfim, foi muito bom e educativo"

"gostei muito de ter de investigar um crime. Sempre sonhei em testar meus conhecimentos, deduções e percepções em um caso de assassinato"

Quando os alunos foram questionados sobre o que menos gostaram, mencionaram a questão do tempo, mas não no sentido de que as atividades não puderam ser realizadas dentro do tempo previsto, mas sim que não conseguiram encontrar o assassino (chegar a um consenso no grupo de quem seria o assassino) já que não relacionaram as evidências coletadas, as análises realizadas e os depoimentos. E assim sentiram necessidade de que o curso tivesse mais um encontro:

"pelo fato de não ter tempo, não conseguimos desvendar o crime, mas isso foi uma coisa do grupo e não do curso"

"acho que tivemos pouco tempo entre um encontro e outro, e deveríamos ter mais encontros"

Outro ponto destacado foi de não poder entrar e coletar evidências na cena, já no primeiro encontro, pois como descrito na proposta didática, no primeiro contato que os alunos tiveram com a cena do crime foi solicitado que apenas observassem e fizessem algumas anotações tanto quanto a parte externa e interna da cena:

"bem o que eu menos gostei foi de não poder mexer nas coisas já no primeiro dia. Sei que era uma regra, mais sou um pouco curioso e isso atrapalhou um pouco"

Também foi mencionada a questão de não saberem a resposta "certa", já que os pesquisadores não informaram aos alunos se tinham conseguido desvendar o caso. Porém, desde o primeiro encontro, os alunos estavam cientes de que eles seriam os peritos, pois foi proposto a eles que imaginassem que tinham sido contratados para desvendar um crime, e que ao final teriam que chegar a algumas conclusões. Foi enfatizado de que não haveria uma resposta correta, 
mas sim a deles, pois assim como na vida real, nunca se sabe o que realmente aconteceu, mas sim o que peritos e investigadores concluem.

"de não saber o resultado, pois a curiosidade era grande"

"acho que do final. Ficamos sem algumas respostas e com 'a grande dúvida':

qual o significado das fotos? O que o culpado (que provamos ser o culpado)

fazia naquele local com a maleta? O que ele entregava para seu parceiro?”

Além disso, relataram que gostaram menos da parte de analisar as impressões digitais coletadas, no sentido de comparara-las com o bando de dados, a fim de descobrir a quem elas pertenciam:

"gostei menos da parte de análise de digitais, pensei que seria mais fácil, mas acabou sendo complicado por não estarem muito visíveis" "a dificuldade de se comparar as digitais complicou um pouco"

Outro ponto destacado pelos alunos foi de que gostariam de interrogar os suspeitos, já que só tiveram acesso aos depoimentos. Também foi apontado de que gostaram de todas as atividades propostas, já que para eles se tratava de algo novo, e ao mesmo tempo, que despertava-Ihes muita curiosidade:

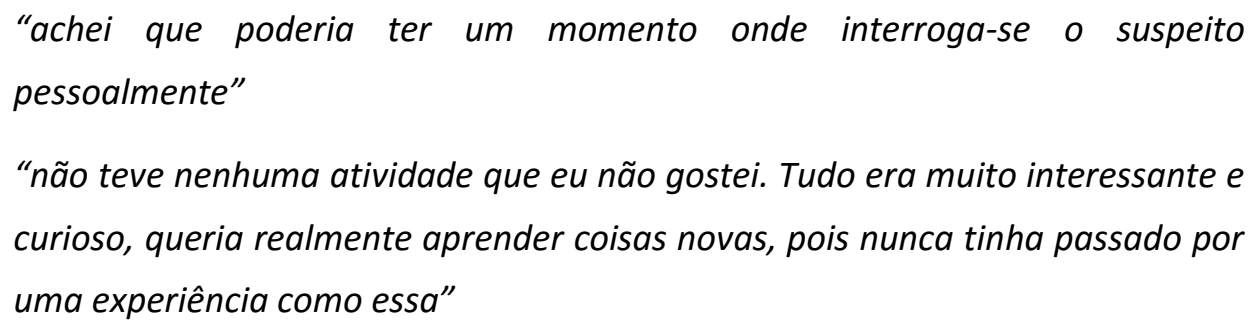

Aparecem ideias de forma a contribuir quando da realização de uma próxima edição, no sentido de melhorar, pois os alunos pensam que o local onde ocorre a simulação do crime deveria ser um espaço destinado somente $a$ isso.

\begin{abstract}
"A questão não é de não ter gostado, apenas uma observação de algo que futuramente pode ser modificado e melhorado. O fato do lugar onde é realizado o projeto. Em vários momentos o grupo não sabia se as evidências encontradas eram do "crime" ou já estavam no local, não fazendo parte do projeto. Deveria haver um lugar planejado, montado especialmente para esse projeto, ai sim, colocando todas as provas e evidências desejadas"
\end{abstract}

A terceira pergunta do questionário solicitava que os alunos explicitassem o que tinham achado da forma como a temática tinha sido abordada durante os encontros. Uma primeira ideia que apareceu foi de que os pesquisadores sempre estiveram orientando as atividades de forma a fazer com que os alunos se tornassem cientes dos materiais que estariam disponíveis para eles e 
quanto aos procedimentos experimentais das análises, além de fornecerem-Ihes os materiais necessários e disponíveis quando solicitados:

"eu gostei, pois vocês sempre nos forneciam o que pedíamos depoimentos, analises e etc."

"eu gostei dos encontros, pois tudo foi explicado, e nos ensinado para depois colocarmos em prática"

Além disso, pode-se perceber que a proposta didática implementada estava planejada de acordo com o nível de entendimento dos alunos, já que mencionaram que a mesma era simples, objetiva e de fácil compreensão:

"gostei, achei bem simples e objetivo, a temática foi sempre utilizada de forma direta. O grupo ficou por dentro dos acontecimentos já ocorridos e tivemos nossas dúvidas a respeito dos materiais usados, todas respondidas.

"foi bem esclarecedora, nossas dúvidas sempre eram respondidas e estava tudo bem claro de um modo fácil para entender"

"achei muito bom. Uma coisa bem prática e direta, nada de rodeios"

Os alunos relataram que a temática desenvolvida havia sido bem estruturada, de modo que a simulação do crime representava quase uma história "real", com depoimentos, relato do oficial de justiça, suspeitos, evidências e análises. Além disso, explicitaram que a mesma se tratava de uma oportunidade única e que se tratava de algo criativo e interessante:

"com certeza, foi uma oportunidade que não se repetirá. Foi muito bem elaborado, foi uma simulação do real, e eu particularmente adoro simulações de coisas reais"

"achei muito criativo e interessante, nunca tinha participado nem visto um trabalho como esse"

"a temática foi muito boa, todos os depoimentos dos suspeitos e a história que aconteceu com a vítima, tudo parecia muito real, isso deixou a temática ainda mais criativa e interessante ao mesmo tempo"

"foi bem legal. Pareceu bem uma investigação criminal verdadeira, com depoimentos, análises e constatações do chefe de polícia."

Também foi possível de perceber a satisfação dos alunos com relação à oportunidade de participar de uma atividade como essa, assim como, a vontade de que no contexto escolar fossem oportunizadas atividades que os despertassem para o "aprender" e que mais atividades como essas fossem desenvolvidas: 
"maravilhosa, pensa isto em sala de aula dá uma tamanha vontade de fazer, descobrir e desvendar; é ciência, é matéria, é conteúdo, é conhecimento"

"foi legal e interessante. Muito criativo pois conseguiu prender minha atenção."

"foi muito interessante. Tudo o que fazia parte desse mistério era novo para nós. É muito importante que aconteça esses tipos de cursos, pois eles mostraram como que trabalham os peritos, qual a função deles na tentativa de desvendar o crime."

Quando solicitado que os alunos escrevessem um pouco sobre o que mais gostariam de saber (interesses e curiosidades), as respostas mais representativas referem-se, a saber, se conseguiram desvendar o crime e encontrar o assassino:

$$
\begin{aligned}
& \text { "gostaria de saber a história real. Se conseguimos ou não desvendar o caso" } \\
& \text { "saber como aconteceu o crime se chegamos perto da resposta certa" } \\
& \text { "o que eu gostaria de saber é quem foi o assassino" }
\end{aligned}
$$

Além disso, os alunos manifestaram a curiosidade sobre algumas coisas especificas que estavam na cena do crime, por exemplo, quanto às fotos, em que lugar elas foram tiradas, quem eram as pessoas que aparecem nelas, o que tinha na maleta preta e porque Robson gostava tanto da natureza. Assim como, a causa do sonífero e os detalhes de como a história foi desenvolvida:

"eu tenho bastante curiosidade de saber quem foi o assassino que matou o Robson, sobre as fotos do mural, de onde foram tiradas" "quem foi que matou (mataram) Robson! Gostaria de saber também quem eram os homens das fotos o que eu tinha na mala, e porque ele gostava tanto de natureza, e também porque tinha sonífero no copo do companheiro(a) que estava com Robson."

"gostaria de saber o real fim do caso, se conseguimos as provas suficientes para prender o culpado. Além disso, saber como criaram tudo, a história, as pistas..."

Outras curiosidades que apareceram, referem-se a como identificar a causa de uma morte e seu procedimento e até quanto tempo depois ainda é possível fazer essa identificação. $E$ gostariam de ter mais conhecimento sobre o processo de DNA, de evidências de sangue, das impressões digitais, do fio de cabelo, e da balística. Assim como, ter a oportunidade de presenciar um depoimento de um caso real e de conhecer todo o processo que os investigadores criminais realizam: 
"tenho curiosidades sobre a parte que tem como responsabilidade detectar a causa da(s) morte(s) nos crimes. Autopsia, necropsia por exemplo. Como funciona, depois de quanto tempo ainda é possivel desvendar a causa, enfim" "como acontece realmente um processo de DNA, como acontece para se achar o dono das impressões digitais, o tamanho do calibre da arma. Já tínhamos uma noção sobre esse assunto, mas com esse curso, tivemos realmente a oportunidade de aprender mais"

"gostaria de saber o real procedimento de um grupo de detetives experiente" "também gostaria de saber como analisar o sangue, como saber se existe alguma digital na pele da vítima, se é que é possível descobrir, ver se tem fios de cabelo e saber analisar. E poder ver alguma pessoa depor.

A quinta pergunta referia-se a aprendizagem, na qual os alunos deveriam relatar se tinham percebido que aprenderam e como perceberam isso. Nas respostas dadas pelos alunos, podemos identificar que o desenvolvimento da atividade permitiu a eles ver a importância dos detalhes e as formas de analisar as evidências coletadas, assim como, conhecer e utilizar reagentes na revelação das digitais e na identificação de drogas e sonífero inertes em um liquido:

"sim, percebemos sim, percebemos quando se diz respeito à atenção, a perceber os pequenos detalhes e as formas de analisar os objetos recolhidos" "sim, pois eu na verdade não sabia nada, aprendemos muito através das digitais, o pó usado para enxergá-las melhor, os reagentes usados para descobrir a substância"

"sim, aprendi a prestar mais atenção nos detalhes e nas pequenas coisas que podem fazer muita diferença"

Os alunos também relataram que aprenderam a como solucionar um crime e encontrar evidências. Outra ideia que apareceu, em termos de aprendizagem, trata-se a não destruir ou danificar evidências e provas em uma cena de crime:

"sim, pois aprendemos os passos para começar a desvendar um crime, achar as pistas"

"percebemos sim. Na medida em que tomamos todos os tipos de cuidados e precauções para não 'destruirmos, perdermos' as evidências, impressões, marcas de sangue, enfim, qualquer tipo de pista"

Além disso, tiveram a oportunidade de conhecer mais sobre impressões digitais, pegadas, sangue e balística através dos módulos didáticos e percebem que aprenderam no 
momento de realizar as análises, ou seja, quando precisam transpor para a prática o conhecimento teórico:

"claro que sim, naqueles polígrafos sobre balística, digitais (...) a gente tem uma noção disso, e depois, na hora de por em prática a gente já nota"

"acho que pelo de ser uma coisa que não temos muita informação, mas sabemos do que se trata, a Ciência Forense nos traz um vasto conhecimento. Cada informação que ouvimos, coletamos foi algo novo, e sim aprendemos muito"

Também mencionaram que aprenderam que na área da criminalística os detalhes devem ser considerados, e que devem explorar, pesquisar, procurar provas e analisar tudo o que pode estar relacionado ao crime. Os alunos perceberam isso no momento de chegarem a alguma conclusão, pois todo o trabalho realizado deveria ser interligado de alguma forma no final, com o objetivo de reunir o máximo de provas para solucionar o caso:

"com esse trabalho, aprendi que na área criminalística tudo deve ser levado muito a fundo, explorado, pesquisado, e todos são culpados até que se prove o contrário. Percebi isso simplesmente porque demoramos um tempo até encontrar o culpado, sendo que ele nem havia sido cotado na nossa lista de suspeitos. Tudo foi feito com um grande questionamento"

"aprendi que na área criminalística tudo deve ser levado em conta, explorado, pesquisado, analisando e obtendo provas. Tudo foi feito com um grande questionamento. Percebemos pela dificuldade de se encaixar as provas"

Nesse sentido, o trabalho de um perito é destacado como algo que não é simples como parece ser, pois além de prestar atenção nos detalhes em uma cena de crime também deve levar em conta os depoimentos e os resultados das análises de forma sistêmica na tentativa de desvendar o caso. Além disso, apontam a dificuldade em chegar a alguma conclusão a partir do procedimento experimental - análises. Outra ideia que aparece, e que é de fundamental importância, é a questão de ter sido uma oportunidade de aprender a trabalhar em equipe.

"claro, eu aprendi bastantes coisas, principalmente como é difícil ser um detetive, em como fazer as análises, no cuidado que devemos ter com as provas, em prestar atenção em cada detalhe, em trabalhar em equipe, e em saber ouvir outras opiniões"

"sim. Através dos novos conhecimentos que adquiri. Foi muito interessante, valeu muito a pena participar do curso, agora já tenho uma noção de como é difícil e complicado o trabalho de um perito" 
"sim eu percebi que aprendi, eu percebo isso por me lembrar de coisas importantes que eu li e observei"

De acordo com o explicitado, pode-se perceber que os alunos se detiveram a explicar o que aprenderam e não mencionaram como esse aprendizado ocorreu. Quando foi perguntado sobre quais atividades mais Ihes chamaram a atenção, os alunos falaram que foi quando tinham que refletir sobre seus conhecimentos sobre casos criminais, e sobre o que pensavam em fazer e como pretendiam solucionar o caso, ou seja, o momento reflexivo e de observação que antecedeu a coleta e análise das evidências contidas na cena do crime. Assim como, o primeiro contato que tiveram com a cena do crime - quando foram convidados a conhecer o local onde o crime ocorreu e se posicionarem como os peritos. Isso demonstra que os alunos gostaram da metodologia utilizada, já que ela fazia com que os alunos se tornassem os protagonistas, se imaginar na história, fazendo parte dela:

"parte "pré" ação, onde a gente estava sentada falando o que sabíamos e o que íamos fazer e porque íamos fazer ... porque isso nos leva a verdade de tudo o que sabemos, depois de tantos 'porquês' fica tudo tão claro"

"a primeira visita ao local do crime. Foi muito legal imaginar que estávamos trabalhando como detetives de verdade, imaginar aquilo como sendo real"

As respostas mais representativas dadas pelos alunos referem-se às atividades de procurar, coletar e analisar experimentalmente as evidências na cena do crime. Nesse sentido, uma primeira ideia que apareceu foi quanto a aprender sobre impressões digitais e como identificá-las usando pó e pincel:

"as atividades que mais chamaram a minha atenção foram as que aprendi sobre as digitais, porque gostei muito de fazer aquilo.

"as marcas de impressões digitais. Pois só com elas podemos chegar em um suspeito mais provável".

"a atividade que mais me chamou a atenção foi o pó que usamos para vermos as digitais. Eu imaginava que era lago mais simples, mas acho que conseguimos decifrar uma"

"a atividade que mais me chamou a atenção foi às análises, tanto químicas como as amostras de digitais e etc"

Outra atividade experimental marcante, oportunizada aos alunos, foi a possibilidade de identificar drogas ou sonífero na bebida, que se encontrava nos copos, por meio de reagentes:

"coletar as provar para analisá-las mais tarde. E as análises das digitais e entorpecentes nas bebidas. Pois é muito interessante como é feito o mesmo" 
"A análise das drogas me chamou atenção. Não sabia que era feito assim"

Assim como procurar, coletar e analisar as evidências, isso se torna marcante para os alunos, pois além de ser uma atividade bastante prática, permite aguçar a sua imaginação no sentido de fazer uma reconstrução da história que ali se passou, e assim procurar pistas que levam a desvendar o caso:
"a procura de pistas nos mais variados lugares"
"pesquisar e analisar as evidências, muito diferente e interessante, pois nunca tinha feito nada parecido e nem tinha ideia de como era feito"
"a parte de coleta de dados e análise. Sempre gostei desse assunto e foi interessante analisar as evidências"
"a parte de identificar uma impressão digital foi bem interessante, e também a parte das provas, de coletar e analisar"
"todas. Todos nós estávamos bastante atenciosos a procura de novas pistas e vestígios deixados pelas pessoas na hora do crime"

Na sétima pergunta, os alunos foram questionados sobre quais foram as atividades que mais proporcionaram informações durante os encontros. Dessa forma, apontaram que foi às atividades de caráter prático - coleta e análise das impressões digitais, assim como, a identificação da substância inerte no copo:

"a identificação das digitais encontradas"

"analisar as digitais, o pó, o copo com a substância, as fotos etc"

E em caráter mais teórico, citaram os arquivos e fotos no computador, as ligações telefônicas e mensagens contidas no celular da vítima, e os depoimentos das pessoas envolvidas. E de caráter prático também mencionaram a análise de DNA por meio da saliva no copo:

"atividade que mais me proporcionou informações foi quando podíamos mexer no computador, olhar as fotos do parque e ver as ligações e mensagens no telefone celular. E claro os depoimentos"

"os depoimentos proporcionaram muitas informações e eles é que levaram a solução do caso. Também foi importante a análise no computador e do DNA na saliva do copo"

"as atividades que mais me proporcionaram informações, conhecimentos, foram analisar as impressões digitais, as pegadas, coletar as provas, analisar o material dos suspeitos como depoimentos e tentar então chegar a uma 
interpretação concreta de quem poça ser o assassino e como aconteceu o crime"

"impressões digitais, já ditas, e as fotos encontradas no computador. Foram extremamente importantes para o desenrolar do crime"

Nesse sentido, podemos concluir que os alunos subentenderam por atividades que geraram, de alguma forma mais informações, aquelas que dessem alguma resposta ou apontassem algum caminho na tentativa de ajudar a solucionar o suposto crime.

E por fim, a última pergunta, solicitava que os alunos escrevessem sobre qual teria sido a vivência que the despertou maior curiosidade durante a sua participação na atividade de desvendar um crime fictício. Uma primeira ideia que apareceu foi com relação à identificação de o que se encontrava embrulhado em um pacotinho branco na cena do crime - o sonífero:

"o que me despertou maior curiosidade foi quando entrei na cena do crime e vi algo embrulhado no papel, pensei em muitas coisas que poderiam estar ali, até que descobrimos que era sonífero"

Também foi mencionada a importância da análise de sangue e de DNA em situações criminais para a identificação do criminoso. E a forma como é realizada a correspondência positiva das impressões digitais coletadas na cena dos crimes com as do banco de dados:

"o que mais me deixou curioso foi justamente a análise de DNA. É muito impressionante como uma marca de nosso corpo é única em todo mundo, e que podemos achar informações sobre alguém simplesmente com uma amostra de DNA"

"a maneira como e feito as pesquisas das impressões digitais e do sangue encontrado no local. É um processo bastante complexo, mas muito interessante, só assim chegaríamos ao nome do culpado"

Outra ideia importante que os alunos apontaram, foi quanto aos momentos de reflexão e discussão entre os colegas, já que essa ação caracterizava-se como uma oportunidade de poderem expor as suas ideias e conclusões aos demais colegas, na tentativa de resolverem o caso, apontando de forma detalhada as provas que os levam a determinado laudo e suas teorias frente à reconstrução do crime:

"sem dúvidas a dos debates; não foi nem o momento de investigar o crime, $e$ sim na hora em que juntávamos o que tínhamos e criávamos teorias e tudo mais"

"todas as análises nos dados e formular o caso, porque juntar todas as informações foi complicado, mas acabou sendo divertido" 
$\mathrm{Na}$ opinião de alguns alunos, as fotos no mural e no computador lhes despertou mais curiosidade, ao mesmo tempo em que ao relacionar com outras provas, a mesma foi de fundamental importância para conseguir apontar o assassino e solucionarem o caso. Outros ainda relataram a história e/ou os motivos pelo qual o crime ocorreu:

"as fotos presas ao mural na parede e as dentro do computador. Pois nelas estava o principal suspeito do assassinato, Carlos"

"o que me despertou mais curiosidade foram às fotos e o motivo do assassinato"

"o final do caso, toda a história com todos os motivos para o crime ter ocorrido"

Pode-se perceber que a atividade em si despertou muito interesse nos alunos, já que a proposta didática implicava que ao final teriam que expor a que conclusões sobre o caso tinham chegado. Ao mesmo tempo em que os deixou ansiosos e inquietos, já que ao final nos questionavam se tinham conseguido desvendar o crime e encontrar todas as evidências e provas implantadas. Ou seja, apresentavam muita curiosidade em conhecer a história que criamos com todos os seus detalhes. Pois apesar de terem conseguido solucionar o caso, sempre ficavam com alguma dúvida, por exemplo, se estavam no caminho certo, se aquela evidência realmente descartava determinado suspeito ou se incriminava de fato o assassino, entre outras:

"minha maior curiosidade é saber quem matou o Robson e também o que havia nas fotos que não estavam no mural e qual o motivo de ter assassinado o Robson"

"a história real do caso, 'quem realmente matou Robson?' e 'quem falava a verdade e quem mentia?"'.

\section{Considerações finais}

A investigação, aqui apresentada, objetivou perceber e identificar as curiosidades e interesses do público participante no curso percebendo o que os levaram a fazer parte do mesmo, o porquê se inscreverem e o que esperavam aprender. Além disso, buscou-se realizar uma avaliação da proposta didática planejada e desenvolvida. Cabe destacar que esta investigação faz parte de uma proposta maior, vinculada a uma pesquisa de mestrado, que visa analisar como o Ambiente Interativo de Aprendizagem (AIA) favorece o desenvolvimento de atitudes investigativas quando envolvidos em um processo didático de caráter investigativo.

Considerando a análise realizada, foi possível perceber que as atividades experimentais oportunizadas aos alunos despertaram grande interesse, já que eles têm pouco ou nenhum 
acesso devido às condições e infraestrutura das escolas. Além disso, foi um momento em que eles tiveram a possibilidade de conhecer os procedimentos realizados pelos peritos com as evidências encontradas em uma cena de crime. Outro ponto a ser destacado é com relação à confirmação da solução do caso, ou seja, os alunos sentiram necessidade de conhecer o final da história - o que realmente aconteceu. Considerou-se isso como algo natural, uma vez que os alunos estão acostumados com situações de ensino realizadas na escola e, assim sendo, quase sempre sabem ou recebem as respostas ditas corretas.

A partir das atividades desenvolvidas e da metodologia empregada (Porlán, 1993), destacam-se alguns aspectos pelos quais acredita-se na eficiência da estratégia didática. Essa foi capaz de estimular a participação ativa dos estudantes, a curiosidade e o interesse, propiciar a construção de um ambiente motivador, agradável e rico em situações novas e desafiadoras. Ambiente este que pode facilitar aos alunos o desenvolvimento de autonomia, do espírito crítico e, principalmente, das atitudes e dos procedimentos investigativos, tais como, formulação de perguntas e de hipóteses, coleta de dados, proposição de procedimentos ou de estratégias para resolução do problema, identificação do problema, entre outras (Brasil, 1998). Foi uma forma de levar o aluno a participar de seu processo de aprendizagem, deixando de lado a postura passiva do modelo tradicional de ensino (Zembal-Saul et al, 2002; Silveira e Ostermann, 2002; Lima, 2004). Desta maneira conclui-se que esta estratégia de ensino, aliada ao assunto da criminalística, despertou grande fascínio nos alunos. Isso foi amplamente percebido nos resultados aqui apresentados, assim como nos depoimentos dos alunos.

\section{Referências}

ACEVEDO, J. A. D. Reflexiones sobre las finalidade de laenseñanza de lascienciaseducación científica para laciudadanía. Revista Eureka sobre Enseñanza y Divulgación de lasCiencias, v. 1, n. 1,p. 3-16, 2004.

ASENSIO, M. El marco teórico delaprendizaje informal. IBER Didáctica de lasCienciasSociales, Geografía e Historia, v. 27, p. 17- 40, 2001.

BASTOS, H. F. B. N; ALMEIDA, M. A. V. de; ALBUQUERQUE, E. S. C. de; MAYER, M.; LIMA, J. M. de F. Modelização de situações-problema como forma de exercer ações interdisciplinares em sala de aula. XVI Encontro de Pesquisa Educacional do Nordeste. Aracajú, 2003.

BELLO, L. La enseñanza de la química general y su vínculo conla vida. Educación Química, v. 11, n. 4, p. 374-394, 2000.

BRASIL. Parâmetros Curriculares Nacionais (Ensino Médio) Parte III - Ciências da Natureza, Matemática e suas Tecnologias. Secretaria de Educação Fundamental. Brasília: A Secretaria, 1998. 
CALAZANS, M. L. Museu Interativo: fazendo e aprendendo ciências. Belo Horizonte, Brasil: UFMG/FAE. Brasil. 95p. (tese de especialização), 1996.

CHEMELLO, E. Ciência Forense: Impressões Digitais. Química Virtual, 2006.

(http://www.quimica.net/emiliano/artigos/2006dez forense1.pdf)

DELICIO, M. P.; GANDINI, A. L.; NUNES, G. A. Museu: ferramenta de Ensino de Ciências. I Simpósio de Pesquisa em Ensino e História de Ciências da Terra e III Simpósio Nacional sobre Ensino de Geologia no Brasil, UNICAMP, Campinas-SP, p. 207-209, 2007.

DELVAL, J. Qué pretendemos enlaeducación? Investigaciónenlaescuela, n. 43, p. 5-14, 2001.

FREIRE, P.Educação como Prática da Liberdade. Rio de Janeiro: Paz e Terra, 1983

FREITAS, F.; MARTINS, I. P. Promover a aprendizagem das ciências no 1으 CEB utilizando contextos de educação não formal. Enseñanza de lasCiencias, n. extra, VII Congreso, p. 1 - 4, 2005.

GALVÃO, C.Educação em Ciência: Das políticas educativas à implementação do currículo. X Encontro Nacional de Ensino em Ciências, na Faculdade de Ciências da Universidade de Lisboa, 2003.

GARCÍA PÉREZ,F. F. Los modelos didácticos como instrumento de análisis y de intervenciónenlarealidad educativa. RevistaBibliográfica de Geografía y CienciasSociales. Universidadde Barcelona, n. 207, 2000. Disponível em http://www.ub.es/geocrit/b3w-207.htm. Acesso em agosto de 2011.

GARCÍA PÉREZ, F. F.; PORLÁN, R. El Projecto IRES (Investigación y Renovación Escolar). Revista Bibliográfica de Geografía y CienciasSociales. Universidad de Barcelona, n.205, 2000. Disponível em http://www.ub.es/geocrit/b3w-205.htm. Acesso em agosto de 2011.

GASPAR, A. O Ensino Informal de Ciências: de sua viabilidade e interação com o Ensino Formal à concepção de um Centro de Ciências. Caderno Catarinense de Ensino de Física. Florianópolis, v. 9, n. 2, p. 157-163, 1992.

GIL, P. D.; CARRASCOSA, C.; MARTÍNEZ, T. J. La Enseñanza de lasCienciasenlaEducación Secundaria. Barcelona: ICE/HORSI, USAB, 1999.

HARRES,J. B.S;PIZZATO, M. C.; SEBASTIANY, A.P.; PREDEBON, F.; FONSECA, M. C.; HENZ, T. Laboratórios de Ensino: inovação curricular na formação de professores de ciências. Santo André: ESETec Editores Associados, 2005.

HOERNING, A. M.; PEREIRA, A. B.As aulas de ciências iniciando pela prática: o que pensam os alunos. Revista Brasileira de Pesquisa em Educação em Ciências, v. 4, n. 3, p. 19-28, 2004.

LIMA, V. A. Atividades experimentais no ensino médio: reflexão de um grupo de professores a partir do tema eletroquímica. Dissertação (Mestrado) São Paulo: USP, 2004.

276 DOI: Em andamento.

R. Bras. de Ensino de C\&T 
MARTINS, I. Educação e Educação em Ciências. Universidade de Aveiro. Departamento de Didáctica e Tecnologia Educativa. 1ạ Edição. Aveiro, 2002.

MATURANA, H. Transformaciónenlaconvivencia. Santiago de Chile: DolmenEdiciones, 2a . Ed, 2002.

MORAES, R.; GALIAZZI, M. C.Análise Textual Discursiva. Ijuí:UNIJUÍ, 2007.

MOREIRA, M. A. Aprendizagem significativa crítica., p.1-24, 2005. Disponível em:

http://www.if.ufrgs.br/ moreira/apsigcritport.pdf.

NOVAIS, R. M.; SANTOS, V. P. A.; SILVA, K. S.; MARCONDES, M. E. R.; SANTOS,J. B.Modelos Didáticos: UmInstrumento para Análise e Reflexão sobre a Prática Docente. XIV Encontro Nacional de Ensino de Química. Curitiba PR: UFPR, 2008.

PEÑA, M. D. Interdisciplinaridade: questão de atitude. In: FAZENDA, I. C. A. (org) Práticas interdisciplinares na escola. 8 ed. Ed. Cortez, São Paulo, SP, 158p, 2001.

PORLÁN, R. Constructivismo y escuela: haciaun modelo de enseñanzaaprendizajebasadoenlainvestigación. Sevilla: Díada, 1993.

POZO, J. I.; CRESPO, M. A. Aprender y enseñarciencia. Madrid: Morata, 2000.

PREDEBON, F. Evolução das concepções didáticas de futuros professores de química sob uma perspectiva investigativa construtivista. 2009. 271p. Dissertação (Mestrado em Educação em Ciências)- Educação em Ciências da vida e saúde, Universidade Federal do Rio Grande do Sul, Rio Grande do Sul, 2009.

RIYIS, M. T. RPG \& Educação: O Uso dos Role-Playing Games (RPG) na Educação. Rede RPG, 2003. (http://www.rederpg.com.br/portal/modules/news/article.php?storyid=445)

RODRIGUES, A. e MARTINS, I. P. Ambientes de Ensino Não Formal de Ciências: impacte nas práticas de professores do 10 ciclo do Ensino Básico. Enseñanza de lasCiencias, n. extra. VII Congreso, p. 1-5, 2005.

ROSA, C. T. W. da; HEINECK, R.; ROSA, Á. B. O despertar para a ciência na pré-escola. Revista Digital de Educación y NuevasTecnologías - Contexto Educativo, n³3, 2004. (http://contextoeducativo.com.ar/2004/4/nota-04.htm)

ROSENFELD, M. Educação informal é melhor caminho para se aprender ciência. Portal Aprendiz, 2005.http://aprendiz.uol.com.br/content/peswotothu.mmp.

SEBASTIANY, A. P.; PIZZATO, M. C.;DEL PINO, J. C.; SALGADO, T. D. M. Visitando, pesquisando, aprendendo e brincando: uma revisão de atividades para o ensino informal de ciências. Revista Brasileira de Ensino de Ciência e Tecnologia, v. 5, n.2, p. 69 - 98, 2012. 
SILVEIRA, F. L.; OSTERMANN, F. A insustentabilidade da proposta indutivista de "descobrir a lei a partir dos resultados experimentais". Caderno Brasileiro de Ensino de Física, v. 19, n. especial,p. 7$27,2002$.

SOBES, J.; VILCHES, A. La introducción de las relaciones Ciencia, Tecnología y sociedadenlaenseñanza de lasciencias y suevolución. EducaciónQuímica,v. 11, n. 4 p. 387-394, 2000.

YIN, R. K. Estudo de Caso - planejamento e métodos. Porto Alegre: Bookman, 3a.ed, 2005.

ZEMBAL-SAUL, C.; HAEFNER, L. A.; AVRAANIDOU, L.; SEVERS, M. e DANA, T.Web-based portfolios: a vehicle for examiningprospectiveelementaryteachers'

developingunderstandingsofteachingscience. Journalof Science TeacherEducation, v. 13, n. 4, p. $283-302,2002$. 


\section{Anexos}

\section{Anexo 1 - Relato do Policial sobre a Cena do Crime}

Tendo a sala de operações da Polícia Militar recebido uma ligação do Sr. Junior Carlos Holmes na sexta-feira pela manhã do dia 04 de dezembro, fui até a casa da vítima, localizada na rua Ciência / no 307 / do bairro Forense, um bairro localizado no subúrbio da cidade. Segundo a mãe da vítima - primeira a encontrar o corpo -, a porta da casa encontrava-se aberta e, ao entrar, visualizei o corpo da vítima de bruços na sala de estar, sem vida a mais de 5 horas segundo os paramédicos que já se encontravam no local. Em volta do corpo havia uma poça de sangue proveniente da cabeça, a qual estava perfurada, provavelmente causada por uma arma de fogo de pequeno ou médio calibre. Ao lado do corpo estava a Mãe da vítima, Sra. Amélia Forensics, juntamente com o autor da ligação, Sr. Junior Carlos Holmes, primeiro vizinho à direita da vítima. Posteriormente, recebemos a informação que o nome da vítima era Sr. Robson Forensics. O local foi totalmente isolado para preservar as evidências e o IGP (Instituto Geral de Perícias) acionado.

\section{Anexo 2 - Banco de dados de Impressões Digitais}

Nome: Geraldo da Silva

Idade: 35 anos

Altura: $1,72 \mathrm{~cm}$

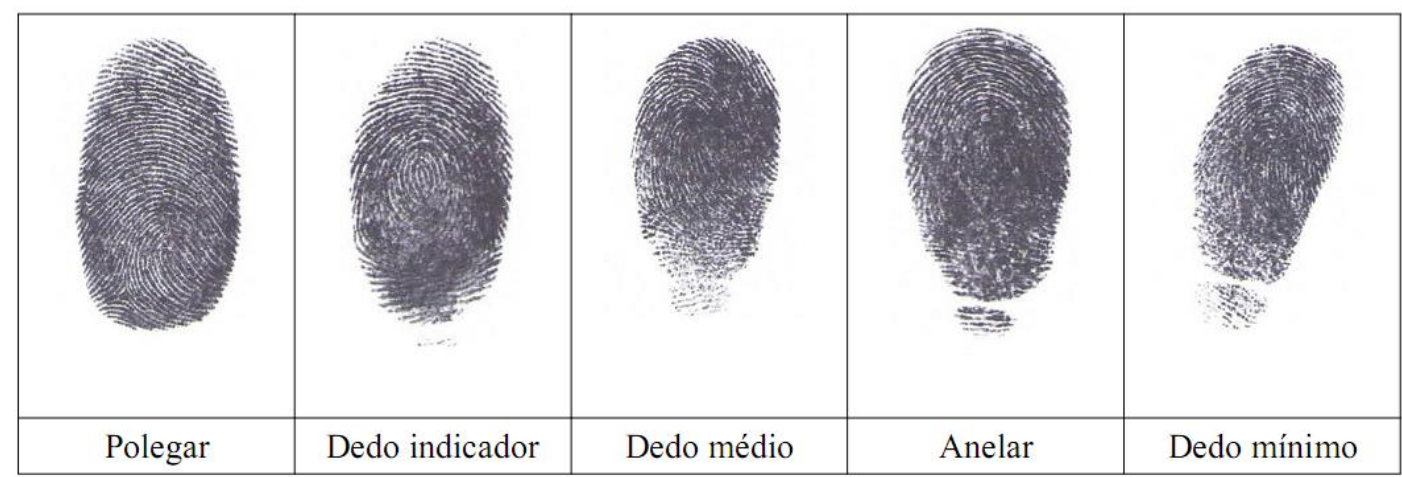


Anexo 3 - Modelo de Bloco de detetive

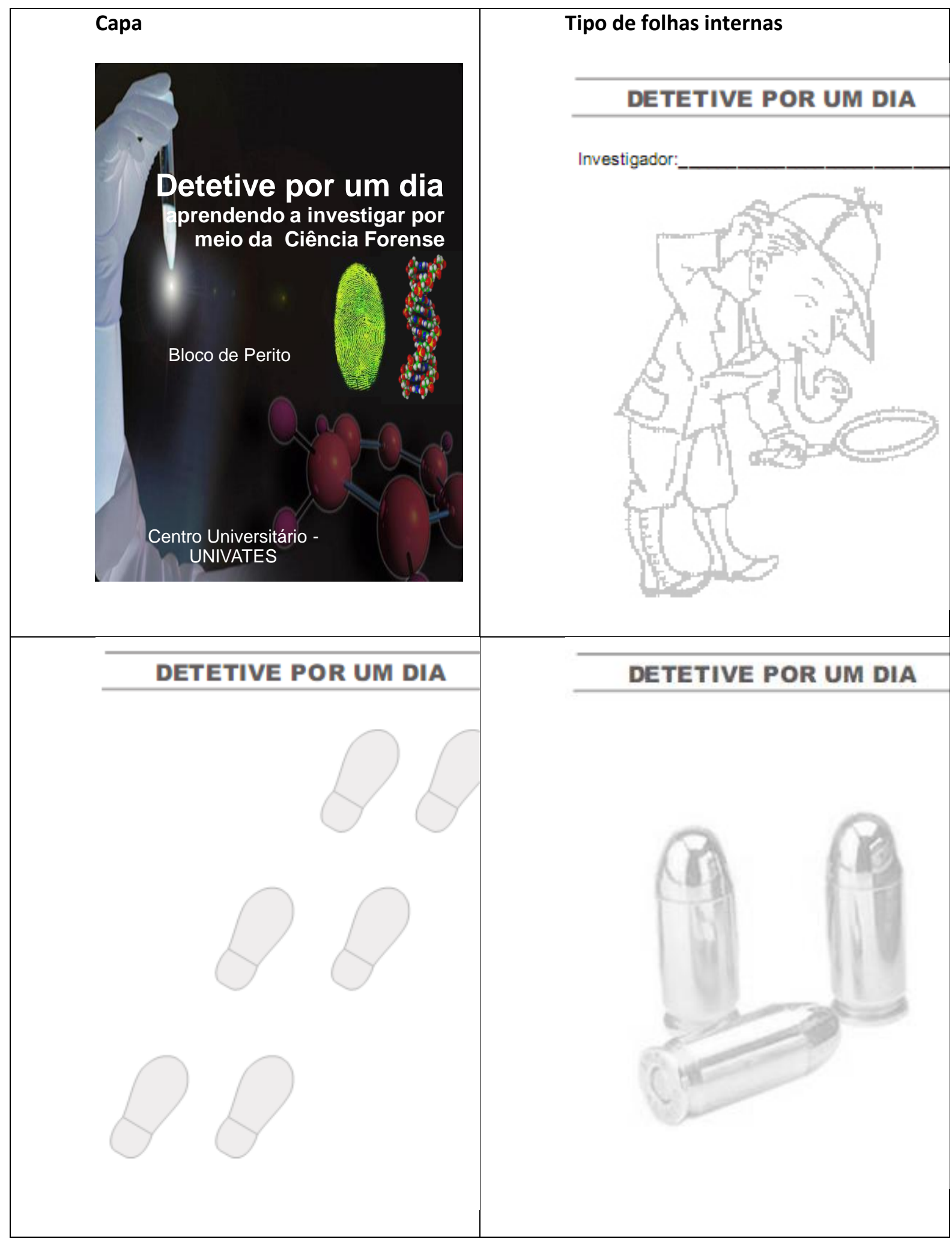




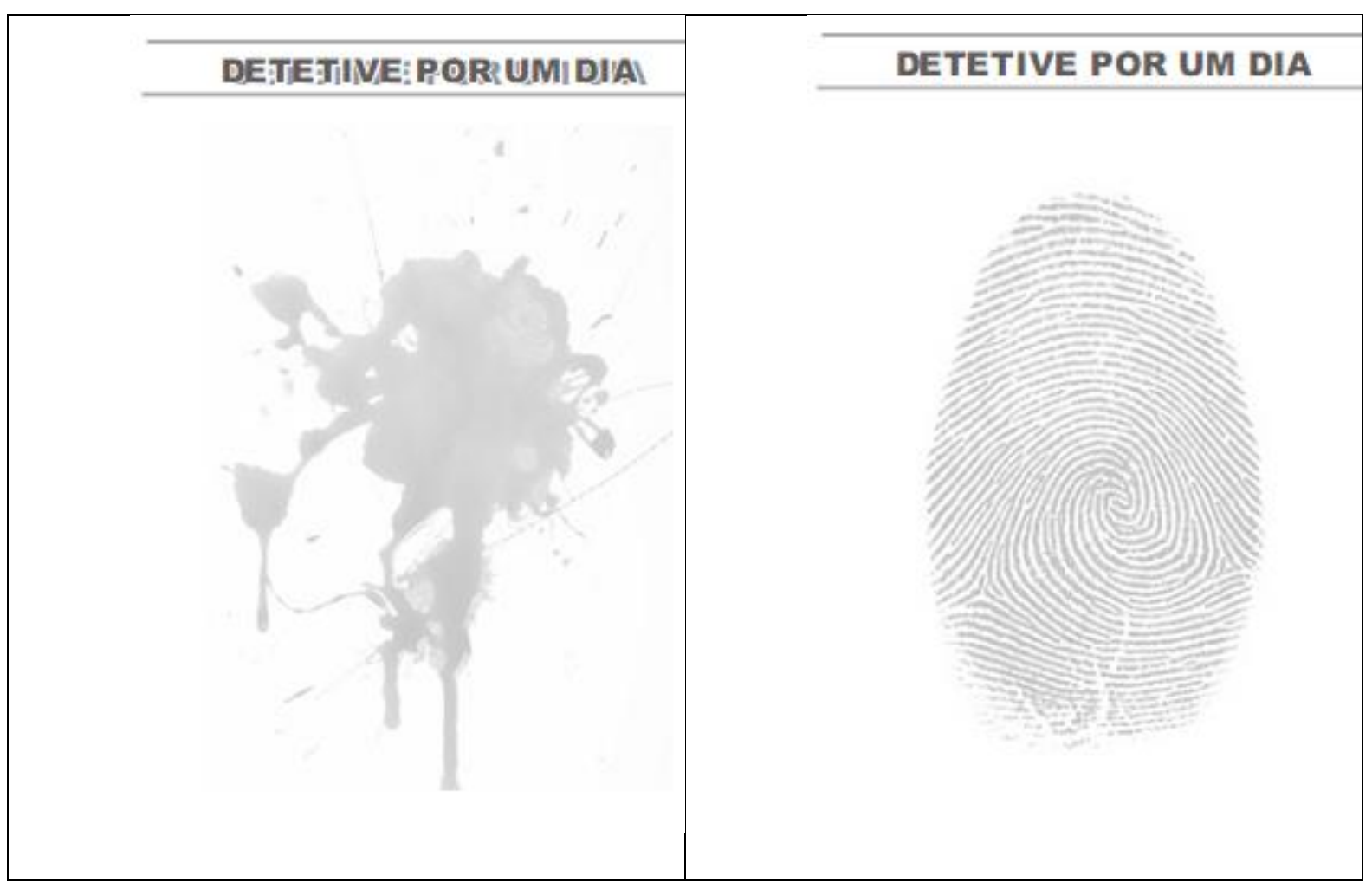


Anexo 4 - Pirâmides de identificação das evidências

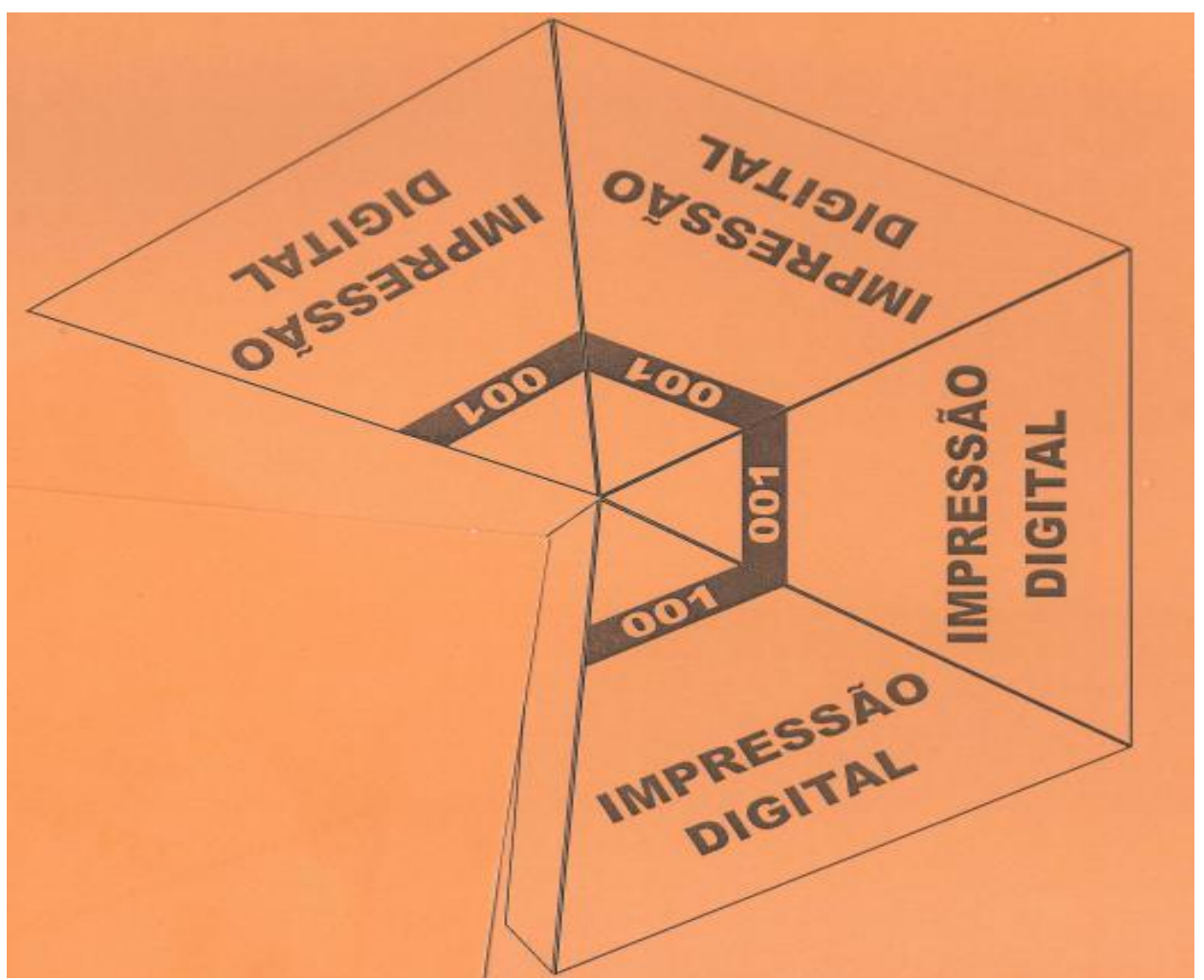


Anexo 5 - Fichas de evidências

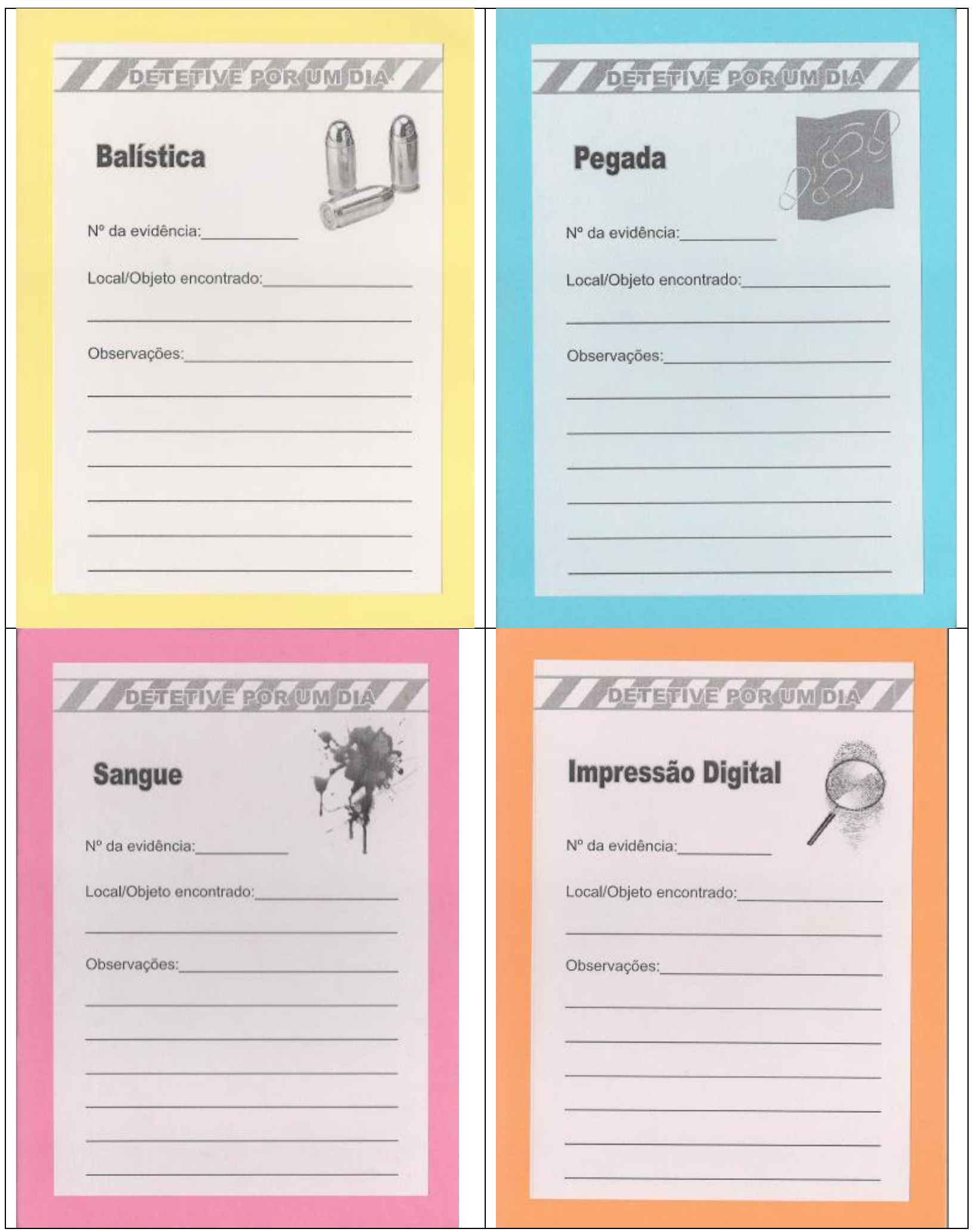

R. B. E. C. T., vol 8, núm. 4, set-dez.2015 


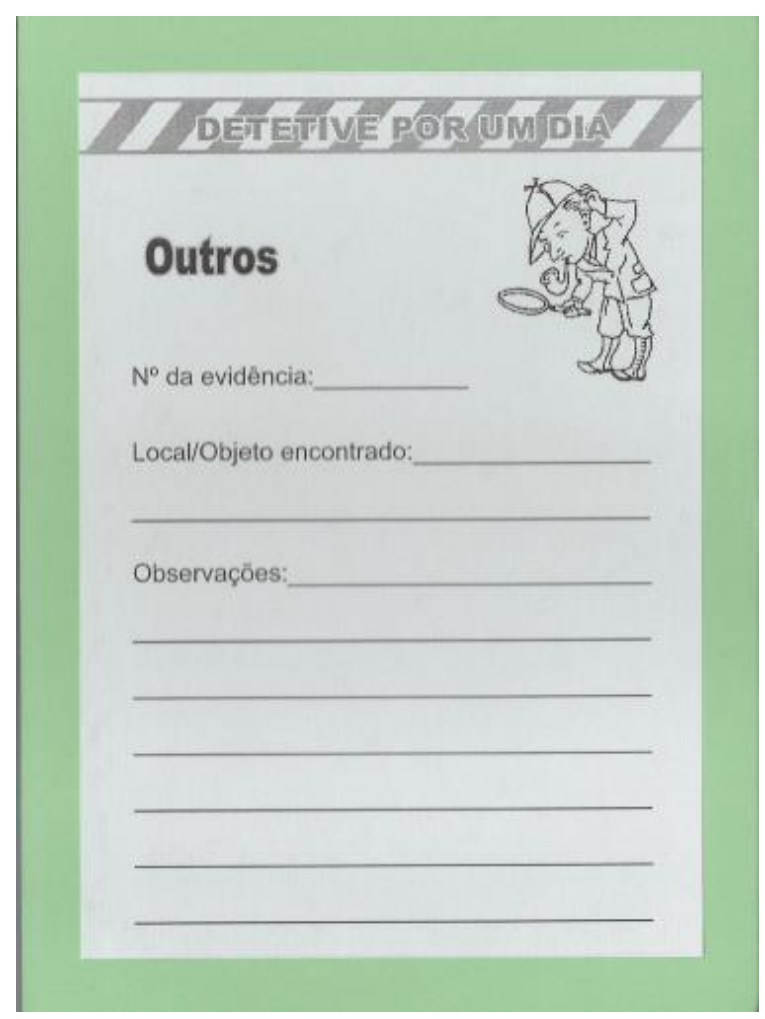




\section{Anexo 6 - Ficha cadastral}

\section{FICHA CADASTRAL}

Nome: Geraldo da Silva

ldade: 30 anos

Altura: $1,72 \mathrm{~cm}$

Ligação com a vitima: vizinho

RG: 9728650842

Naturalidade: Lajeado/RS

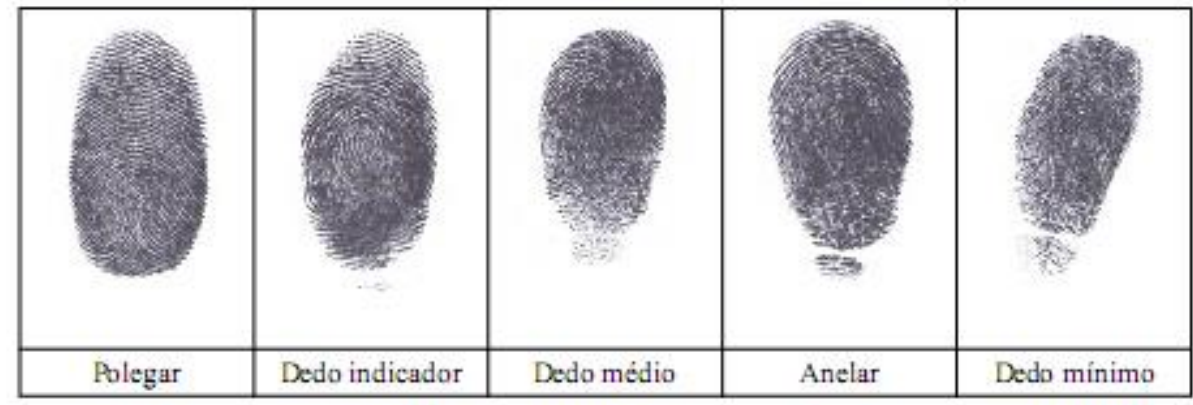


Álibis:

Indícios que levariam ao crime:

Evidências encontradas na cena do crime:

Observações: 
Ana Paula Sebastiany: Mestre em Educação em Ciências - UFRGS.

anapaulaslajeado@yahoo.com.br

Michelle CamaraPizzato: Professora do Instituto Federal de Educação, Ciência e Tecnologia do Rio Grande do Sul. Porto Alegre, RS, Brasil. michelle.pizzato@poa.ifrs.edu.br

Tania Denise Miskinis Salgado: Professora Associada do Instituto de Química da Universidade Federal do Rio Grande do Sul. tania.salgado@ufrg.br 